\title{
A confirmatory factor analysis of the spanish language version of the Attitudes Toward Lesbians and Gay Men Scale (ATLG)*
}

Análisis factorial confirmatorio de la versión en español del Cuestionario de Actitudes hacia Lesbianas y Hombres Gais (ATLG)

Recibido: febrero 9 de 2010 | Revisado: diciembre 14 de 2010 | Aceptado: enero 25 de 2011

\author{
Jaime Eduardo Barrientos Delgado ** \\ MANUEl CÁRDENAS CASTRO*** \\ Universidad Católica del Norte, Chile
}

\begin{abstract}
A B S T R A C T
This paper intends to validate the Attitudes toward Lesbians and Gay Men Scale (Herek, 1988). The starting point is the five dimensions reported in previous studies (Cárdenas \& Barrientos, 2008). No research has confirmed the hypothesized ATLG factor structure with a Spanish-language sample. This study tested three factor structures, results indicating that the twofactor second-order model provides the best description of ATLG items. Additionally, psychometric properties were examined using a sample of 518 college students. ATLG proved reliable $(\alpha=0.93)$ and valid for Chilean population.

Key words authors

Confirmatory factor analysis, sexual prejudice, Attitudes toward Lesbians and Gay men scale (ATLG).

Key words plus

Psychological tests, psychometry, quantitative research, validation.
\end{abstract}

\section{RESUMEN}

Este artículo busca validar la Escala de Actitudes hacia Lesbianas y Hombres Gais ([ATLG], Herek, 1988). El punto de partida son las cinco dimensiones reportadas en estudios anteriores (Cárdenas \& Barrientos, 2008). Ninguna investigación ha confirmado la estructura factorial hipotética de la ATLG con una muestra de hispanoparlantes. El estudio examinó tres estructuras factoriales, y los resultados indican que el modelo de dos factores proporciona la mejor descripción de los ítems de la ATLG. Además, se examinaron las propiedades psicométricas con una muestra de 518 estudiantes universitarios. La ATLG se mostró confiable $(\alpha=0.93)$ y válida para una población chilena.

Palabras clave autores

Análisis factorial confirmatorio, prejuicio sexual, Escala de Actitudes hacia Lesbianas y Gais.

Palabras clave descriptores

Pruebas psicológicas, psicometría, investigación cuantitativa, validación. 
The most common measure of sexual prejudice is the Attitudes toward Lesbians and Gay Men Scale (Herek, 1984). Sexual prejudice refers to negative attitudes based on sexual orientation, whether their target are lesbians or gay men (Herek 2000, 2004). This measure has shown good psychometric properties in a series of studies (Herek, 1988) and has been adapted and validated for its use in Latin population living in the U.S.A. (Herek \& González Rivera, 2006; Cárdenas \& Barrientos, 2008). Studies to reveal the qualities of this measure do not show its underlying dimensions. They have focused on exploratory factor analysis and only a few of them have examined models for their composition and provided sound indications of measure validity and construct composition. Only Stoeber and Morera (2007) did the study with an English-language sample. There is a noticeable lack of standardized instruments in the Spanish language assessing attitudes towards gay men and lesbian and its factor structure.

The ATLG current version was developed from a set of 128 items measuring attitudes toward gay men and lesbians (Herek, 1984). Twenty of these items showing the highest item-total correlations (10 that make up an ATL scale and 10 for ATLG) were selected. The ATLG first study and its abbreviated versions (Herek \& González Rivera, 2006) indicate that each subscale is unidimensional, though no further data exists on this issue. Thus, the main objective of this study is to make an ATLG confirmatory-type factor analysis.

The main purpose of the present study was to further address the dimensionality of the ATLG Spanish Language Version. A confirmatory factor analysis was employed. To prove ATLG scale dimensionality three factor models were used. The first one emphasizes the scale unidimensionality, so all items are expected to saturate in one general homophobia factor. The second model hypothesizes that subscales ATL and ATG are separate but correlated factors, so the 10 items corresponding to each of them are expected to saturate. Finally, a second order model with two correlated factors named ATL and ATG. The ATL factor consists of the 3 sub-scales (Traditional Values, Social Sanction and
Social Rights). The ATG factor includes 2 sub-scales (Beliefs and Nature).

Additionally, on the basis of this study and the findings from previous research, we hypothesize that:

H1: Women are expected to report lower levels of sexual prejudice than men for both the total scale and those of attitude toward gay men and lesbians.

H2: People who report themselves as religious are expected to obtain higher scores in the total scale and subscales. In comparing more religious people with those moderately religious and slightly religious differences are expected to be significant. So, the higher the religious involvement or the higher the importance given to religious ideas, the greater the prejudice levels toward homosexuals.

$\mathrm{H} 3$ : Subject's political standing is considered, so those further left in the political continuum may be more prejudiced than those further right. Subjects in central political standing may be more moderate than the other two groups.

H4: Significant differences are expected between subjects belonging to the various socioeconomic levels, those in the higher classes reporting more negative attitudes.

\section{Method}

\section{Participants}

The participants in this study were 518 college students from Chile. Fourteen participants who reported themselves as homosexual $(n=5)$, bisexual $(n=5)$, or did not report their sexual orientation $(n=4)$ were excluded from the analysis because this study is geared toward the evaluation of sexual prejudice among heterosexuals. The final sample consisted of 504 participants, 240 women (47.61\%) and 264 men (52.39\%) whose ages ranged from to 17 to 53 years $(M=20.34, S D=3.16)$.

\section{Procedures}

This study is part of a broader piece of research on group relations and related attitudes toward differ- 
ent social groups. All participants were tested after giving their consent in writing. Respondents were assured anonymity to complete a set of paper-andpencil questionnaires on ATLG measures individually. Volunteers received extra credit points for their course grade. The ethical criteria of the Chilean Research Commission (CONICYT) were followed.

\section{Measures}

\section{Social and demographic measures}

Participants answered demographic questions to test ATLG validity: sex, age, socioeconomic status (high, middle and low levels were used), and religion identification through self-reporting on the answer to the question "Do you consider yourself a religious person?" Additionally, a 4-item scale measure on a 6-point Likert scale regarding the importance participants give to their religious ideas in their daily lives was used. In addition, political self-categorization (asking about political preferences coded on three categories: left, center and right) and sexual orientation were included.
Attitudes toward Lesbians and Gay Men

ATLS is a 20 -item measure consisting of two scales, attitudes toward lesbians (ATL) and gay men (ATG). It was developed in Northern America. ATLG is measured on a 6-point Likert scale. High (close to 6) scores showed greater prejudice, and low scores reported favorable attitudes toward homosexuals. The instrument was translated and adapted (Cardenas \& Barrientos, 2008) (see the Appendix). The ATLG Spanish language version in this study had not been used with Chilean populations before. The Cronbach's alpha was 0.94 for ATLG; 0.88 for ATL; and 0.91 for ATG (The ATLG and the two subscales demonstrated good internal consistence for this sample. The correlation for the two subscales is high $\left(r_{(503)}=0.84 ; p<0.001\right)$. ATLG overall mean was $3.52(\mathrm{SD}=0.75)$.

\section{Results}

\section{Sample characteristics}

Table 1 shows the ATLG descriptive statistics for the different socio-demographic variables.

TABLE 1

Socio-demographical variables

\begin{tabular}{lccccc}
\hline \multicolumn{1}{c}{ Variable } & $\mathrm{N}$ & $\%$ & ATL & ATG & ATLG \\
\hline Sex & & & & & \\
$\quad$ Female & 240 & 47.61 & $3.08(0.68)$ & $3.5(0.94)$ & $3.29(0.78)$ \\
$\quad$ Male & 264 & 52.39 & $3.78(0.59)$ & $3.66(0.77)$ & $3.72(0.65)$ \\
$\begin{array}{l}\text { Socio-economic level } \\
\quad \text { Upper }\end{array}$ & 122 & 24.3 & $3.66(0.69)$ & $3.3(0.97)$ & $3.48(0.78)$ \\
$\quad$ Middle & 275 & 54.8 & $5.68(0.66)$ & $3.44(0.89)$ & $3.55(0.75)$ \\
$\quad$ Low & 105 & 20.9 & $3.57(0.62)$ & $3.38(0.83)$ & $3.47(0.7)$ \\
Religion & & & & & \\
$\quad$ Non-religious & 240 & 51.7 & $3.58(0.65)$ & $2.29(0.85)$ & $3.44(0.72)$ \\
$\quad$ Religious & 224 & 48.3 & $3.73(0.66)$ & $3.51(0.93)$ & $3.62(0.77)$ \\
Political self-categorization & & & & & \\
$\quad$ Right & 193 & 38.8 & $3.88(0.64)$ & $3.73(0.79)$ & $3.8(0.64)$ \\
$\quad$ Central & 189 & 38.1 & $3.59(0.66)$ & $3.33(0.88)$ & $3.45(0.74)$ \\
$\quad$ Left & 115 & 23.1 & $3.38(0.68)$ & $2.94(0.9)$ & $3.16(0.74)$ \\
\hline
\end{tabular}

Note. Standard deviations are given in parenthesis.

Source: own work. 


\section{Confirmatory Factor Analysis (CFA)}

The main objective was to determine the underlying ATLG factor structure. So, three factor models were estimated: a one-factor model (ATLG consists of a single homophobia factor in which all items saturate); a two-factor correlated model (two dimensions comprised by ATL and ATG subscales whose items should saturate in the corresponding factor are proposed) and a second order model with two correlated factors (in which ATG subscale items would saturate in two dimensions - homosexual Beliefs and Nature - and those of the ATL scale would saturate in the other three - lesbian Traditional Values, and Social Sanction and Social Rights). These five dimensions were taken from analyses done in previous studies (Cárdenas \& Barrientos, 2008).

Table 2 shows the fit indexes for confirmatory models. Comparison reveals that the two-factor second order model behaves best.

In general, the fit is better when model factors are increased. Thus, the two-factor second order model is the most parsimonious for all indexes obtained. CFI (Comparative Fix Index) and NFI (Normal Fit Index) indexes show values over 0.9, all of them regarded as very good (Bentler \& Dudgeon, 1996). RFI (Relative Fix Index) value approaches 0.9 , particularly in the five-factor model. Additionally, RMSEA (Root Mean Square Error of Approximation) index is significant with values lower than 0.08 (Browne \& Kudeck, 1993), thus confirming the best fit of the five-factor model.

Table 3 also shows the factor saturations for each of the five sub-scales model items. All standardized saturations were significant $(p<0.001)$. All of the 20 items of the standardized solution loaded on the general grouping factor in the expected direction. The relation between the five latent factors is as follows (covariance): the dimension Social Rights has a high positive correlation with the factor $\mathrm{Na}$ ture $(r=0.6)$; moderate positive with both Social Rights $(r=0.43)$ and Social Sanction $(r=0.038)$; and high positive with Traditional Values $(r=0.74)$. The dimension Nature is moderately and positively correlated with Social Rights $(r=0.32)$ and Social Sanction $(r=0.35)$, but highly and positively correlated with Traditional Values $(r=0.61)$. The relation of the dimension Social Rights with Social Sanction $(r=0.31)$ and Traditional Values $(r=0.37)$ is moderate high. Finally, the relation between Traditional Values and Social Sanction is moderate positive $(r=0.43)$.

\section{The effect of demographic variable on Attitudes toward Gay Men and Lesbians}

In order to study the relation between the ATLG scale and other variables reported relevant in the literature on homophobia, a multiple regression (standard model) analysis was made to test sex effect, socioeconomic level, religion, and political self-categorization.

As a whole, the four variables give account of $44 \%$ of the dependent variable variance (ATLG), the linear relation among variables being significant $\left(F_{(4,487)}=29.46 ; p<0.001\right)$. The most important variable in the regression equation is political selfcategorization $(\beta=-0.30 ; p<0.001)$, followed by sex $(\beta=0.28 ; p<0.001)$ and religion $(\beta=-0.11$; $p<0.05)$. The socioeconomic level variable has no effect on ATLG scores.

TABLE 2

Fit statistics for all models of the ATLG Spanish Language Version

\begin{tabular}{lccccccc}
\hline \multicolumn{1}{c}{ Model } & $\chi^{2}$ & $d f$ & $p$ & CFI & NFI & RFI & RMSEA \\
\hline One factor & 913.25 & 170 & 0.000 & 0.87 & 0.84 & 0.81 & 0.09 \\
Two Correlated Factor & 686.41 & 169 & 0.000 & 0.91 & 0.88 & 0.85 & 0.08 \\
Two factor second order model & 534.46 & 160 & 0.000 & 0.93 & 0.91 & 0.88 & 0.06 \\
(five sub-scales) & & & & & & & \\
\hline
\end{tabular}

Source: own work. 
TABLE 3

Five sub-scale a two-factor second order model: Standardized factor loadings

\begin{tabular}{|c|c|c|}
\hline & Item & Model \\
\hline \multirow{6}{*}{ 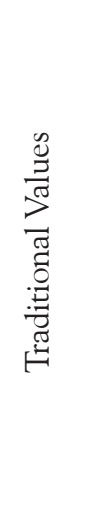 } & $\begin{array}{l}\text { "Female homosexuality is detrimental to society because it breaks down the } \\
\text { natural division between the sexes" }\end{array}$ & 0.79 \\
\hline & "Female homosexuality is a sin" & 0.78 \\
\hline & "The growing number of lesbians indicates a decline in American moral". & 0.74 \\
\hline & "Female homosexuality is a threat to many of our basic social institutions" & 0.75 \\
\hline & "Female homosexuality is a inferior form of sexuality" & 0.58 \\
\hline & Lesbians are sick & 0.77 \\
\hline \multirow{2}{*}{ 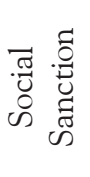 } & "State lows regulating private, consenting lesbian behavior should be loosened" & 0.49 \\
\hline & $\begin{array}{l}\text { "Female homosexuality in itself is no problem, but what society makes of it can } \\
\text { be a problem" }\end{array}$ & 0.66 \\
\hline \multirow{2}{*}{ 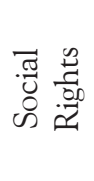 } & “Lesbians just can't fit into our society & 0.66 \\
\hline & $\begin{array}{l}\text { A woman's homosexuality should not be a cause for job discrimination in any } \\
\text { situations" }\end{array}$ & 0.67 \\
\hline \multirow{7}{*}{ 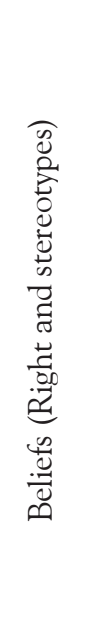 } & $\begin{array}{l}\text { "Male homosexual couples should be allowed to adopt children the same as } \\
\text { heterosexual couples" }\end{array}$ & 0.63 \\
\hline & "I think male homosexuals are disgusting" & 0.73 \\
\hline & "Male homosexuals should not be allowed to teach school" & 0.66 \\
\hline & "Male homosexuality is a perversion" & 0.87 \\
\hline & $\begin{array}{l}\text { "If a man has homosexual feelings, he should do everything he can to overcome } \\
\text { them" }\end{array}$ & 0.76 \\
\hline & "The idea of male homosexual marriages seems ridiculous to me" & 0.8 \\
\hline & "Male homosexuality is merely a different kind of lifestyle that should not be" & 0.75 \\
\hline \multirow{3}{*}{ 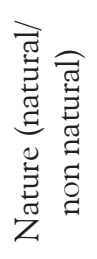 } & $\begin{array}{l}\text { "Just as in other species, male homosexuality is a natural expression of sexuality } \\
\text { in human men" }\end{array}$ & 0.7 \\
\hline & "I would not be too upset if I learned that my son was a homosexual" & 0.58 \\
\hline & "Homosexual behavior between two men is just plain wrong" & 0.82 \\
\hline
\end{tabular}

Source: own work. 
Men report higher homophobia levels tan women, as well as more negative attitudes toward lesbians than toward gay men $\left(t_{(272)}=4.94 ; p<0.001\right)$. These differences are also reported by women, showing that they assess female homosexuality more negatively than male homosexuality $\left(t_{(241)}=11.36\right.$; $p<0.001$ ).

Finally, results above show that religious subjects and those who identify with the right in the political continuum have more negative attitudes toward homosexuals. Among religious subjects, those who give more importance to religion also reported a more negative attitude, though only in assessing lesbians $\left(F_{(2,274)}=3.89 ; p<0.05\right)$.

\section{Discussion}

Considering the good fit of the models, factors increase as model fit increases. So, the two-factor, second order model proposed achieves the best fit, giving the ATLG structure greater flexibility. Results support the hypothesis that the ATLG factor structure is complex and would not aim at measuring a general factor of sexual prejudice, and that ATG and ATL, although closely correlated, allow obtaining a differentiated measure of prejudice toward gay men and lesbians.

The factor that best explains negative attitudes toward lesbians is the questioning their presence poses on Traditional Values. This questioning of values involves the transgression of gender roles established and the questioning of women's role in the social structure. The other two ATL dimensions refer to both lesbian's Social Rights and the Social Sanction that comes from their rights and traditional role transgression. That is the reason for this role transgression to be so negatively assessed in "machista" societies like the Chilean one and for lesbians to obtain attitude measures less favorable than gay men from both heterosexual men and women assessing them. The case of gay men is slightly different since ATG dimensions focus on other issues. Beliefs about male homosexuality and its nature are important. Previous studies indicate that gay men are evaluated more negatively if they are supposed to be able to control their sexual pref- erence (Sakalli, 2002; Verweij et al., 2008), that is, when homosexuality is an option attitudes are more negative. Maybe, that is why the factor Beliefs groups together with Rights since although they are theoretically separable, gay men rights would depend or be closely linked with the attributions heterosexual subjects give to homosexuality nature.

Female gender role transgression is more punished than that of gay men because the latter only quit a certain privileged position with their option, thus placing themselves at the same level as any other social minority group. The existence of an anti-minority bias deeply rooted in more conservative societies must be remembered to explain prejudice levels. Lesbians are different because their self-affirmation questions the possibilities of reproducing a social model based on male dominion. They claim an equalitarian position in the social hierarchy. Accepting that a man is gay involves that some of them are not gay any more, but accepting a lesbian implies a reformulation of the social hierarchy. Results show that prejudice levels toward gay men are low, this transgression being more sociably tolerable than that of lesbians.

ATLG scale properties are robust and thus make it a good indicator of the population attitude toward the two groups and, therefore, the scale division remains pertinent. Unlike other studies (Stoeber \& Morera, 2007) this one shows that ATLG is not a general discrimination index (general underlying factor), but it assesses two groups which, although having common treats (showing high correlation), they contain differential elements that make them being assessed with special factors. Anyway, the scale assessed remains pertinent to distinguish these attitude groups, regardless of the fact that these differences were not considered during its elaboration.

Finally, the social transgressions that affirmation of sexual identification involves are those which play a central role in attitude development, while prejudice deals with societal segmentation and hierarchization. So, the transgression of traditional values and gender roles associated is still regarded as socially inconvenient since it questions both the dominion of some groups over others and the existing social hierarchy. Thus, religious 
individuals and right wingers could consistently assess homosexuals lower since they play extremely rigid gender roles. In addition, they punish female transgression more than male transgression since women question these values and roles, while men only put them aside.

The study has some limitations it is necessary to comment. In first order, the questionnaire analyzed does not lack the common problems occurring in self-reported measurements. These problems refer to the facts that people significantly differ in their capacity to be aware of their own internal states (Nisbett \& Wilson, 1977); they are not always willing to show their attitudes publicly due to their apprehension for evaluation (Rosenberg, 1969); and that they try to correct their impressions (Tedeschi, Schlenker, \& Bonoma, 1971) or judgments as they occur in order to adjust them (Greenwald \& Banaji, 1995; Petty \& Wegener, 1998).

Another limitation relates to the convenience undergraduate sample used. The generalizability limits with such types of samples are documented, but in Chile research on this issue is just starting. Therefore, the data reported here should be viewed as preliminary.

\section{References}

Bentler, M. P. \& Dudgeon, P. (1996). Covariance structure analysis: Statistical practice, theory and directions. Annual Review of Psychology, 47, 563-592.

Browne, M. W. \& Kudeck, R. (1993). Alternative ways of assessing model fit. En K. A. Bollen \& J. S. Long (Eds.), Testing structural equation models (pp. 136162). Newbury Park, CA: Sage.

Cárdenas, M. \& Barrientos, J. (2008). The Attitudes toward Lesbians and Gay Men Scale (ATLG): Adaptation and testing the reliability and validity in Chile. Journal of Sex Research, 45(2), 140-149.

Greenwald, A. \& Banaji, M. (1995). Implicit social cognition: Attitudes, self-esteem and stereotypes. Psychological Review, 102, 4-27.

Herek, G. M. (1984). Beyond "homophobia": A social psychological perspective on attitudes toward lesbians and gay men. Journal of Homosexuality, 10(1-2), 1-21.
Herek, G. M. (1988). Heterosexuals' attitudes toward lesbians and gay men: Correlates and gender differences. Journal of Sex Research, 25, 451-477.

Herek, G. (2000). Sexual prejudice and gender: Do heterosexuals' attitudes toward lesbians and gay differ? Journal of Social Issues, 56(2), 251-266.

Herek, G. (2004). Beyond "homophobia": Thinking about sexual prejudice and stigma in the twentyfirst century. Sexuality Research \& Social Policy, 1(2), 6-20.

Herek, G., \& González Rivera, M. (2006). Attitudes toward homosexuals among U.S. residents of Mexican descendent. Journal of Sex Research, 43(2), 1-25.

Nisbett, R. \& Wilson, T. (1977). Telling more than we can know: Verbal reports on mental processes. Psychological Review, 84, 231-259.

Petty, R. E. \& Wegener, D. T. (1998). Attitude change: Multiple roles for persuasion variables. En D. Gilbert, S. Fiske \& G. Lindzey (Eds.), The Handbook of social psychology (4. ${ }^{\text {a }}$ ed., pp. 323-390). New York: McGraw-Hill.

Rosenberg, M. J. (1969). The conditions and consequences of evaluation apprehension. En R. Rosenthal \& R. L. Rosnow (Eds.), Artifact in behavioral research (pp. 279-349). New York: Academic Press.

Sakalli, N. (2002). Application of the attribution-value model of prejudice to homosexuality. Journal of Social Psychology, 142, 264-271.

Stoeber, C. \& Morera, O. (2007). A confirmatory factor analysis of the Attitudes toward Lesbians and Gay Men (ATLG) Measure. Journal of Homosexuality, 52(3-4), 189-208.

Tedeschi, J., Schlenker, B. \& Bonoma, T. (1971). Cognitive dissonance: Private ratiocination or public expectacle? American Psychologist, 26, 685-695.

Verweij, K., Shekar, S., Zietsch, P., Eaves, L., Bailey, J. M., Boomsma, D. \& Martin, N. (2008). Genetic and environmental influences on individual differences in attitudes towards homosexuality: An Australian twin study. Behavioral Genetics, 38(3), $257-265$. 


\section{Appendix}

\section{a) The Attitudes toward Gay men subscale (ATG) and their Spanish translation}

1. A las parejas de hombres homosexuales debería permitírseles adoptar hijos como a las parejas heterosexuales. [Male homosexual couples should be allowed to adopt children the same as heterosexual couples.]

2. Pienso que los hombres homosexuales son repugnantes. [I think male homosexuals are disgusting.]

3. A los hombres homosexuales no debería permitírseles enseñar en los colegios. [Male homosexuals should not be allowed to teach school.]

4. La homosexualidad masculina es una perversión. [Male homosexuality is a perversion.]

5. La homosexualidad masculina es una expresión natural de la sexualidad masculina. [Just as in other species, male homosexuality is a natural expression of sexuality in human men.]

6. Si un hombre tiene sentimientos homosexuales, debería hacer todo lo posible para superarlos. [If a man has homosexual feelings, he should do everything he can to overcome them.]

7. Si supiera que mi hijo es homosexual yo no estaría deprimido/a. [I would not be too upset if I learned that my son was a homosexual.]

8. El sexo entre dos hombres no es natural. [Homosexual behavior between two men is just plain wrong.]

9. La idea del matrimonio homosexual me parece ridícula. [The idea of male homosexual marriages seems ridiculous to me.]

10. La homosexualidad masculina es un tipo diferente de opción de vida que no debería ser condenada. [Male homosexuality is merely a different kind of lifestyle that should not be condemned.]

\section{b) The Attitudes toward Lesbians subscale (ATL) and their Spanish translation}

1. Las lesbianas no deberían ser integradas en nuestra sociedad. [Lesbians just can't fit into our society.]

2. La homosexualidad de una mujer no debería ser una causa de discriminación. [A woman's homosexuality should not be a cause for job discrimination in any situation.]

3. La homosexualidad femenina es mala para nuestra sociedad porque rompe la división natural entre los sexos. [Female homosexuality is detrimental to society because it breaks down the natural divisions between the sexes.]

4. Las leyes que castigan la conducta sexual consentida por dos mujeres adultas deben ser abolidas. [State laws regulating private, consenting lesbian behavior should be loosened.]

5. La homosexualidad femenina es un pecado. [Female homosexuality is a sin.]

6. El número creciente de lesbianas indica una declinación de los valores fundamentales de nuestra sociedad. [The growing number of lesbians indicates a decline in American morals.]

7. La homosexualidad femenina por sí misma no es un problema a menos que la sociedad la transforme en un problema. [Female homosexuality in itself is no problem but what society makes of it can be a problem.]

8. La homosexualidad femenina es una amenaza para muchas de nuestras instituciones sociales básicas como la familia. [Female homosexuality is a threat to many of our basic social institutions.]

9. La homosexualidad es una forma inferior de sexualidad. [Female homosexuality is an inferior form of sexuality.]

10. Las lesbianas son enfermas. [Lesbians are sick.] 